\title{
MYCORRHIZAL DEVELOPMENT AND PLANT GROWTH in Inoculated and Non-Inoculated Plots of California Native Grasses and Shrubs
}

\author{
James R Salyards, Richard Y Evans, and Alison M Berry |
}

\section{ABSTRACT}

Roots of California brome (Bromus carinatus Hook and Arn. [Poaceae]) and tufted hairgrass (Deschampsia caespitosa (L.) Beauv. [Poaceae]) were more rapidly colonized by arbuscular mycorrhizal fungi (AMF) when grown in plots containing commercial or naturally occurring AMF inoculum, but after 68 wk plants growing in non-inoculated plots had similar colonization and biomass production. Both species would serve as satisfactory carriers of AMF to restoration sites, but Deschampsia supported a higher concentration of spores. Indeed, both species of grass were effective in supplying AMF to Arroyo willow (Salix lasiolepis Benth. [Salicaceae]), but subsequent biomass accumulation of the willow was not associated with either inoculation or root colonization. We conclude that inoculation with AMF is unnecessary except in sites where early colonization is essential.

KEY WORDS

Bromus carinatus, Deschampsia caespitosa, Salix lasiolepis, Glomus intraradices, restoration, Poaceae, Salicaceae, AMF, mycorrhizal fungi, inoculation

NOMEN CLATURE (plants) Hickman (1993); (fungi) Walker and Trappe (1993)

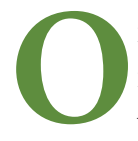
ne of the major challenges in native plant restoration is that growing conditions are often extremely unfavorable for plant establishment. The importance of the belowground component in restoration cannot be underestimated. Many soils to be revegetated, such as gravel layers, roadcuts, and minespoils, are derived from parent material. These soils are often nutritionally poor, lacking in organic matter, and lacking soil microorganisms important for nutrient cycling (Johnson and McGraw 1988; Pfleger and others 1994). It is of interest to the practitioner to determine whether the addition of beneficial microorganisms can create a soil environment conducive to plant growth.

Mycorrhizal fungi are necessary for the establishment and growth of many plant species. Disturbed ecosystems can have dramatically lower levels of mycorrhizal fungi than undisturbed areas (Moorman and Reeves 1979; Boerner and others 1996), even when the two are adjacent. Root colonization rates in disturbed areas have been reported to increase from $1 \%$ to more than $90 \%$ in 1 y after inoculation (Medve 1984). Recently, interest has been increasing in the role of arbuscular mycorrhizal fungi (AMF) for restoration and revegetation (St John 1997). The two most common practices are to inoculate the plants during nursery production or during outplanting (Stahl and others 1988). Inoculant can be grown in a greenhouse or nursery (St John and Evans 1990).

Soil inoculant may be used as a starter (St John and Evans 1990), or cultures can be initiated from mycorrhizal fungi collected on the site to be revegetated (Castellano and Molina 1989; Sharma and others 1996). The use of a fungal inoculant indigenous to the revegetation site has been commonly recommended as an inoculant source (Trappe 1977; Perry and others 
1987; Sharma and others 1996). Native mycorrhizal fungi typically produce higher root colonization rates and significantly greater growth in plants than fungi taken from other locations (Hetrick and others 1986; Greipsson and El-Mayas 2000). Properly stored topsoil is an excellent source of beneficial soil microbes including AMF (Miller and others 1985; Claassen and Zasoski 1993). Claassen and Zasoski (1993) showed that application of reserved topsoil was more beneficial than fertilizer alone in establishing plants.

Perry and others (1987) found that growing grass or some other herb on the topsoil helped prolong the colonization potential of the fungi. "Carrier plants," such as grasses, have been recommended to increase the number of AMF propagules in soils for subsequent plantings (St John and Evans 1990). Atkinson (1983) found that in grassed orchards, mycorrhizal colonization of apple roots increased under a grass cover, as did phosphorus uptake, presumably by providing a high inoculum density for the sparse apple roots. Grasses themselves have been shown to benefit from inoculation in revegetation programs (Hetrick and others 1986; Sylvia 1989). Native grasses have not yet been evaluated for their capacity to serve as carrier plants in revegetation.

In this pilot study, our first objective was to compare colonization levels and performance of 2 California native perennial bunchgrasses, California brome (Bromus carinatus Hook and Arn. [Poaceae]) and tufted hairgrass (Deschampsia caespitosa (L.) Beauv. [Poaceae]), when inoculated either with a commercial AMF inoculant or with a native soil inoculant. Our second objective was to evaluate whether these grasses could be used as carrier plants to propagate AMF for improved establishment of a woody native, Arroyo willow (Salix lasiolepis Benth. [Salicaceae]).

\section{MATERIALS AND METHODS}

\section{Raised Bed Construction}

In spring 1992, 2 trenches $10.9 \mathrm{~m}$ long by $1.1 \mathrm{~m}$ wide by 1.2 $\mathrm{m}$ deep $(36 \mathrm{ft} \times 3.6 \mathrm{ft} \times 4 \mathrm{ft})$ were dug at the experimental fields adjacent to the Department of Environmental Horticulture, University of California, Davis (UCD). A 30-cm (1-ft) high wooden frame was constructed around each trench (Figure 1). We lined the framed trenches with $2 \mathrm{~mm}$ black plastic to limit contamination from native soil, then filled them with a uniformly mixed sandy loam soil (10.6 ppm phosphorus) excavated from the UCD Putah Creek Campus Reserve and used to approximate a low-nutrient soil. The soil was covered with plastic and fumigated with methyl bromide (Great Lakes Chemical Corp, West Lafayette, Indiana) for $48 \mathrm{~h}$, then uncovered and allowed to ventilate for several days.

\section{Inoculation}

On 30 June 1992, we divided each bed into eight $1.1 \mathrm{~m}^{2}$ (12 replicate plots per bed to each of $2 \mathrm{AMF}$ inoculum treatments and 2 controls. The plots were arranged as regularly interspersed replicates (Hurlbert 1984). Two sources of inoculum served as treatments: commercial and duff. The commercial inoculant (Brokaw Nursery Inc, Saticoy, California) consisted of Glomus intraradices Schenck and Smith [Glomaceae] grown in beds of gravelly sand, seeded with Sudan grass (Sorghum sudanense (Piper) Stapf [Poaceae]) as described by Hetrick and Bloom (1986). The inoculant was a mixture of moist sand and grass roots.

Duff was a mixture of decomposed forest litter and soil containing decaying plant material and microorganisms including mycorrhizal fungal spores. We combined 5 duff samples collected by Pacific Gas and Electric Company employees in the vicinity of their Helms Pump Storage Project at Wishon Reservoir, Fresno County (elevation 2150 m [7050 ft]) in December 1991. They collected duff samples from beneath several native species: greenleaf manzanita (Arctostaphylos patula E. Greene [Ericaceae]), incense cedar (Calocedrus decurrens (Torrey) Florin [Cupressaceae]), mountain whitethorn (Ceanothus cordulatus Kellogg [Rhamnaceae]), tufted hairgrass, and California black oak (Quercus kelloggii Newb. [Fagaceae]). We combined the duff samples, sifted them through $0.6 \mathrm{~cm}(0.25$ in) hardware cloth, then stored them at $4{ }^{\circ} \mathrm{C}\left(39^{\circ} \mathrm{F}\right)$ until inoculation. The final duff material contained no roots.

Our 2 controls consisted of an uninoculated control and an organic control plot amended with a steam-sterilized soilless mix (1 part each peat, composted fir bark, and coarse sand).

We mixed each inoculum source with the steam-sterilized soilless mix so that we applied 9.51 (2.5 gal) of commercial inoculum and $2.7 \mathrm{~kg}$ (6 lb) of duff to each of their respective plots, resulting in the inoculum-soilless mix depth of $1.3 \mathrm{~cm}$ (0.5 in) recommended by Menge and Timmer (1982). We spread a $1.3 \mathrm{~cm}$ ( $0.5 \mathrm{in}$ ) layer of reserved fumigated soil over the uninoculated control plots, and covered the organic control plots with $1.3 \mathrm{~cm}$ (0.5 in) of steam-sterilized soilless mix. Approximately $2.5 \mathrm{~cm}$ ( $1 \mathrm{in}$ ) of reserved soil was spread over all plots after inoculum placement (Menge and Timmer 1982; Castellano and Molina 1989).

The resulting inoculum density for the commercial and duff treatments was gauged using spore counts of the 2 inocula (see section on spore counts). Spore density for the commercial inoculum was 15.6 spores/g soil, or 24 spores $/ \mathrm{cm}^{2}$ per plot when applied as inoculum. Spore density for the duff inoculum was 45.9 spores/g soil, or 10 spores $/ \mathrm{cm}^{2}$ per plot when inoculated.

\section{Sowing}

In each inoculum and control treatment plot, we seeded half with California brome (Pacific Coast Seed Inc, Pleasanton, California, Lot \#91CABRO1/CA) and the other half with tufted hairgrass (Pacific Coast Seed Inc, Pleasanton, California, Lot\# B8-1-14/MT). The seeding rates were 0.3 seeds $/ \mathrm{cm}^{2}$ (2 


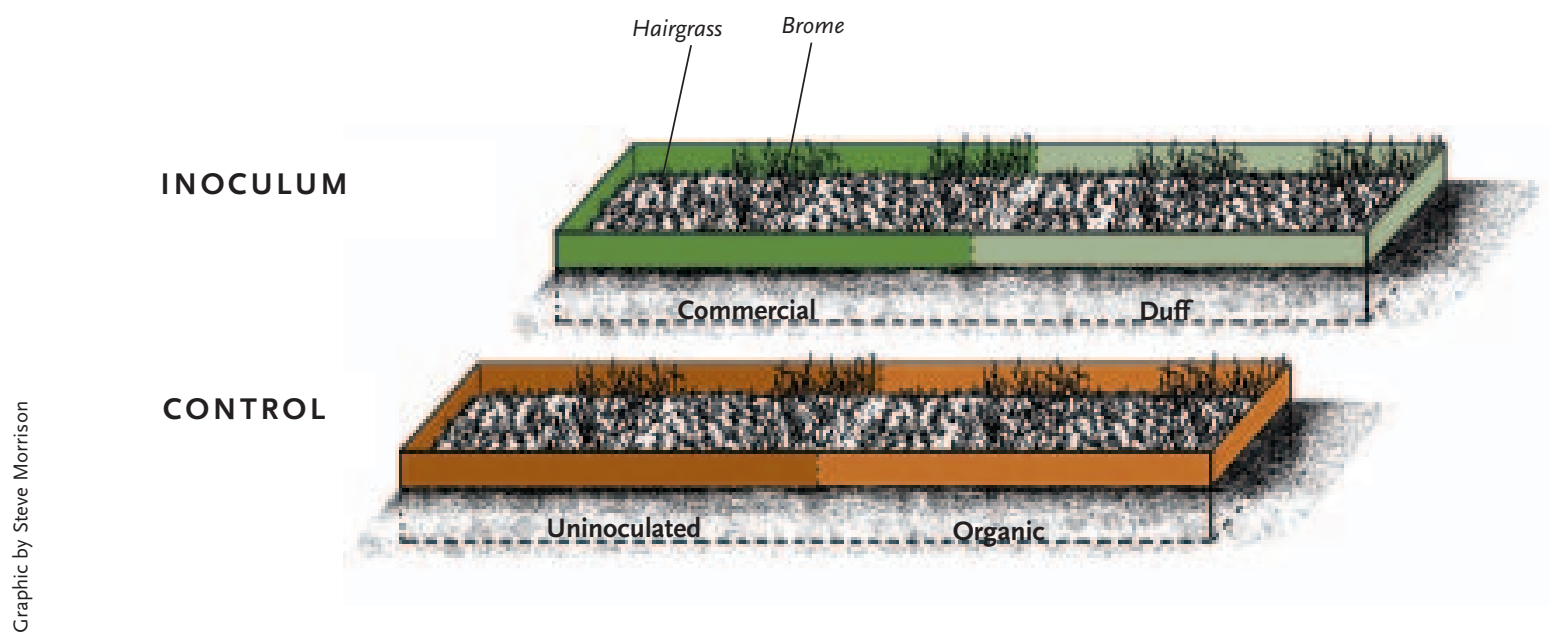

Figure 1. Schematic of experimental design.

seeds $/ \mathrm{in}^{2}$ ) for California brome and 0.6 seeds $/ \mathrm{cm}^{2}\left(4\right.$ seeds $\left./ \mathrm{in}^{2}\right)$ for tufted hairgrass (Figure 1). After sowing, we spread a $3 \mathrm{~mm}$ (0.125 in) layer of soil over the plots and tamped it down. Beds and seedlings were irrigated frequently with a mist emitter drip system until fall rains began. Irrigation was turned off from October through May.

\section{AMF Colonization of Grass Roots}

Root samples from the 2 grass species were taken at 14,34 , and $68 \mathrm{wk}$ post inoculation. Five to 10 soil cores $(2.3 \times 39 \mathrm{~cm}[0.9$ $x 15$ in]) were taken from each plot at each sampling date. We divided cores into three $13 \mathrm{~cm}$ ( 5 in) sections to assess colonization rates at soil depths 0 to $13 \mathrm{~cm}, 13$ to $26 \mathrm{~cm}$, and 26 to $39 \mathrm{~cm}$. To collect roots, soil sections were sieved in a $2 \mathrm{~mm}$ soil sieve, washed with a high-pressure spray nozzle. Additionally, three 20 $\mathrm{cm}$ (8 in) soil cores were taken from each plot at each sampling time and dried at $150^{\circ} \mathrm{C}\left(300^{\circ} \mathrm{F}\right)$ for $2 \mathrm{~d}$. These were sieved $(1$ $\mathrm{mm}$ sieve) and used to count and identify AMF spores.

\section{AMF Root Colonization Determination}

We cleared and stained roots according to the methods of Phillips and Hayman (1970). Washed roots were cut into $1 \mathrm{~cm}$ (0.4 in) pieces, covered with $10 \% \mathrm{KOH}$ and autoclaved at $105^{\circ} \mathrm{C}$ $\left(221^{\circ} \mathrm{F}\right.$ ) for 45 (brome) or 30 (hairgrass) min. Roots were rinsed in deionized water, neutralized in a $1 \% \mathrm{HCl}$ solution for $10 \mathrm{~min}$, stained in $0.05 \%$ Trypan blue stain solution for $24 \mathrm{~h}$, and destained with $98 \%$ lactic acid for $24 \mathrm{~h}$. Roots were stored in fresh lactic acid at $25^{\circ} \mathrm{C}\left(77^{\circ} \mathrm{F}\right)$ until microscopic examination of mycorrhizal colonization. The gridline intersect method (Giovannetti and Mosse 1980) was used to determine root colonization. Root samples in lactic acid were placed in a $9 \times 9 \mathrm{~cm}$ gridded petri dish (Fisher Scientific). The samples were agitated to distribute the root segments evenly. Roots were then examined for colonization at 250X. Counts of roots intersecting every grid line were made noting colonization at each intersection. Colonization was scored as the presence of hyphae, vesicles, arbuscules, or chlamydospores per root length. The root colonization rate was determined as the number of root segment intersects colonized/total number root segment intersects sampled.

\section{Grass Biomass Determination}

All brome leaves per plot were clipped to the crown at 7, 13, 33,71 , and $95 \mathrm{wk}$. Tufted hairgrass was harvested only at 71 and $95 \mathrm{wk}$ due to lower productivity. Clippings were oven-dried at $65{ }^{\circ} \mathrm{C}$ for $72 \mathrm{~h}$ and then weighed.

\section{Inoculation of Willows}

Arroyo willows in $4 \times 13.5 \mathrm{~cm}(1.5 \times 5$ in $)$ tree tubes were purchased from Cornflower Farm Nursery (Elk Grove, California), who collected cuttings from wild plants growing in Winters, California, and planted in March 1993. In each plot, we removed 6 evenly spaced circular plugs ( 16 to $24 \mathrm{~cm}$ [ 6 to 9 in] in diameter) of grass and tilled the soil using a trowel. We pruned the willow plants so that all were roughly the same size, and planted them in the holes. The plants were watered thoroughly after planting, then drip-irrigated for $30 \mathrm{~min}, 4$ times per wk, with additional supplemental spot watering twice a week. We stopped irrigating when fall rains began on 8 Nov 1993. Fifty-seven weeks after planting, the tops were harvested, cut into pieces, and fresh weights determined. Plants were dried at $65^{\circ} \mathrm{C}\left(150^{\circ} \mathrm{F}\right)$ for $72 \mathrm{~h}$. We excavated the below-ground portion of the willows, then removed and cleared the small-diameter roots using a modification of the procedure of Phillips and Hayman (1970). Two root samples from each plot were thoroughly washed, cut into 1 - to 2 -cm segments, treated with $3 \%$ hydrogen peroxide to remove tannins, autoclaved $1 \mathrm{~min}$ at $105^{\circ} \mathrm{C}\left(300^{\circ} \mathrm{F}\right)$, and then rinsed in deionized water. Roots were then autoclaved in $10 \% \mathrm{KOH}$ for $1 \mathrm{~min}$ at $105^{\circ} \mathrm{C}\left(300^{\circ} \mathrm{F}\right)$, cooled to $90^{\circ} \mathrm{C}\left(195^{\circ} \mathrm{F}\right)$, boiled for $2 \mathrm{~min}$ at $105^{\circ} \mathrm{C}\left(300^{\circ} \mathrm{F}\right)$, and finally cooled to $84^{\circ} \mathrm{C}\left(183^{\circ} \mathrm{F}\right)$. Then roots were stained, examined, and stored as described above. 


\section{Spore Counts}

Soil samples were taken 34 and 68 wk after the grass inoculation experiment was started. The procedure of Gerdemann and Nicolson (1963) for spore extraction was followed with some slight modifications. For each treatment, $10 \mathrm{~g}$ of dry soil was brought to $40 \mathrm{ml}$ with water, stirred for $30 \mathrm{~min}$, vortexed and centrifuged at $2500 \mathrm{rpm}$ for $10 \mathrm{~min}$. The supernatant was poured off along with the floating organic matter. The spores remained in the pellet. Sucrose (2 M) containing 2\% Alconox (w:v) was added to the sample to $35 \mathrm{ml}$ total volume, the sample stirred and centrifuged again for $10 \mathrm{~min}$ at $2500 \mathrm{rpm}$. The supernatant was poured into a separatory funnel and the water allowed to drip slowly. Spores were rinsed from the separatory funnel with deionized water and poured into a petri dish. Spores were counted using a dissecting microscope at 25X. Additionally, the sucrose solution was poured into a petri dish and any spores that did not cling to the funnel walls were counted.

\section{Data Analysis}

We used 2-way analysis of variance to evaluate effects of the 4 inoculum treatments and the 2 grass species on AMF colonization of brome and hairgrass roots (after 14, 34, and $68 \mathrm{wk}$ ), spore counts (after 34 and $68 \mathrm{wk}$ ), cumulative grass biomass (after $95 \mathrm{wk}$ ), AMF colonization of willow roots (57 wk after planting), and willow biomass (57 wk after planting). When significant treatment effects were found, we used the TukeyKramer method for multiple comparisons (Kramer 1956). All statistical calculations were performed using Minitab software (Minitab Inc, State College, Pennsylvania).

\section{RESULTS}

Both inoculum $(P<0.001)$ and species $(P<0.006)$ significantly affected AMF colonization of grass roots at $14 \mathrm{wk}$ after inoculation (Figure 2A), with no significant interaction between inoculum and species. The highest percent colonization resulted from inoculation with duff, with a significant increase in AMF colonization in the commercial inoculum treatment as well, compared with control. Colonization rates were significantly higher in brome compared to hairgrass. Root colonization increased in the commercial inoculum, organic control, and uninoculated control treatments over the next year (Figure 2B), however, such that neither inoculum nor species effects were significant by $68 \mathrm{wk}$. Initially the upper soil layer had the highest rate of colonization, but the difference among soil depths decreased over time (data not shown). Ultimately, the colonization rates at the lower soil depths were higher than in the top layer.

Mycorrhizal fungal spore counts were not significantly different among the treatments at the beginning of the experiment or after 34 wk (data not shown). By week 68, the spore count in the duff treatments was 30 spores/g, more than twice that in any other treatment $(P<0.009$, Figure 2C). Hairgrass plots had 20 spores/g soil, significantly more than the 12 spores/g in the brome plots $(P$ $<0.05)$. The cumulative weight of the brome leaves removed from the plots was $2636 \mathrm{~g}$ (93 oz), compared to $1216 \mathrm{~g}$ ( $43 \mathrm{oz}$ ) removed from the hairgrass plots (Figure 1D), a significant difference $(P<$ $0.001)$. Inoculation did not significantly affect grass biomass (2010 g [71 oz] from inoculated plots, compared to $1842 \mathrm{~g}$ [65 oz] from non-inoculated plots).

Both inoculum $(P<0.001)$ and grass species $(P<0.001)$ significantly affected AMF colonization of willow roots, with a significant interaction $(P<0.001)$. Colonization was greater in the hairgrass plots than in the brome plots (Figure 2E), and higher rates of colonization were observed in the duff inoculum, commercial inoculum, and organic control treatments of hairgrass, compared with hairgrass uninoculated control or any of the brome treatments. Some differences were noted among treatments across both grass species, but these were not related to inoculation, as duff inoculum and uninoculated control were not significantly different.

The biomass of willow plants grown on the hairgrass plots was almost 5X greater than that of willows grown in the brome plots $(P<0.005)$. The willows grown in the organic control plots were more than $4 \mathrm{X}$ to $10 \mathrm{X}$ larger than those grown in other treatments. The plots differed in the number of surviving willow plants, but analysis of either total biomass or average biomass of the willow plants gave similar results (data not shown). Reported values represent average biomass per plant (Figure 2F).

\section{DISCUSSION}

Initial colonization of brome and hairgrass roots by AMF occurred much more rapidly in inoculated plots compared with the uninoculated control plots. However, within 68 wk inoculation no longer significantly affected AMF colonization of grass roots or the productivity of either grass species, results which support previous findings by Harris and others (1989) and Sylvia and Jarstfer (1994). Inoculation may thus be unnecessary in many revegetation and restoration projects. By contrast, in sites with seriously degraded or altered soils, such as mine spoils and deep road cuts, mycorrhizal recolonization may be considerably slower than what we observed in our experiments in nutrient-poor topsoil (Claassen and Zasoski 1993). Inoculation with mycorrhizae may be appropriate in such situations, or when rapid, early colonization of plants is desired (for example, for rapid stabilization of soil for erosion control).

Duff proved to be a better source of AMF in early colonization of the grasses than commercial inoculant. Root colonization rate was higher in duff-treated grasses even though the commercial inoculum initially had a higher spore number and, unlike duff, also contained AM-colonized root fragments. Others have also found that native sources of inoculum are more 

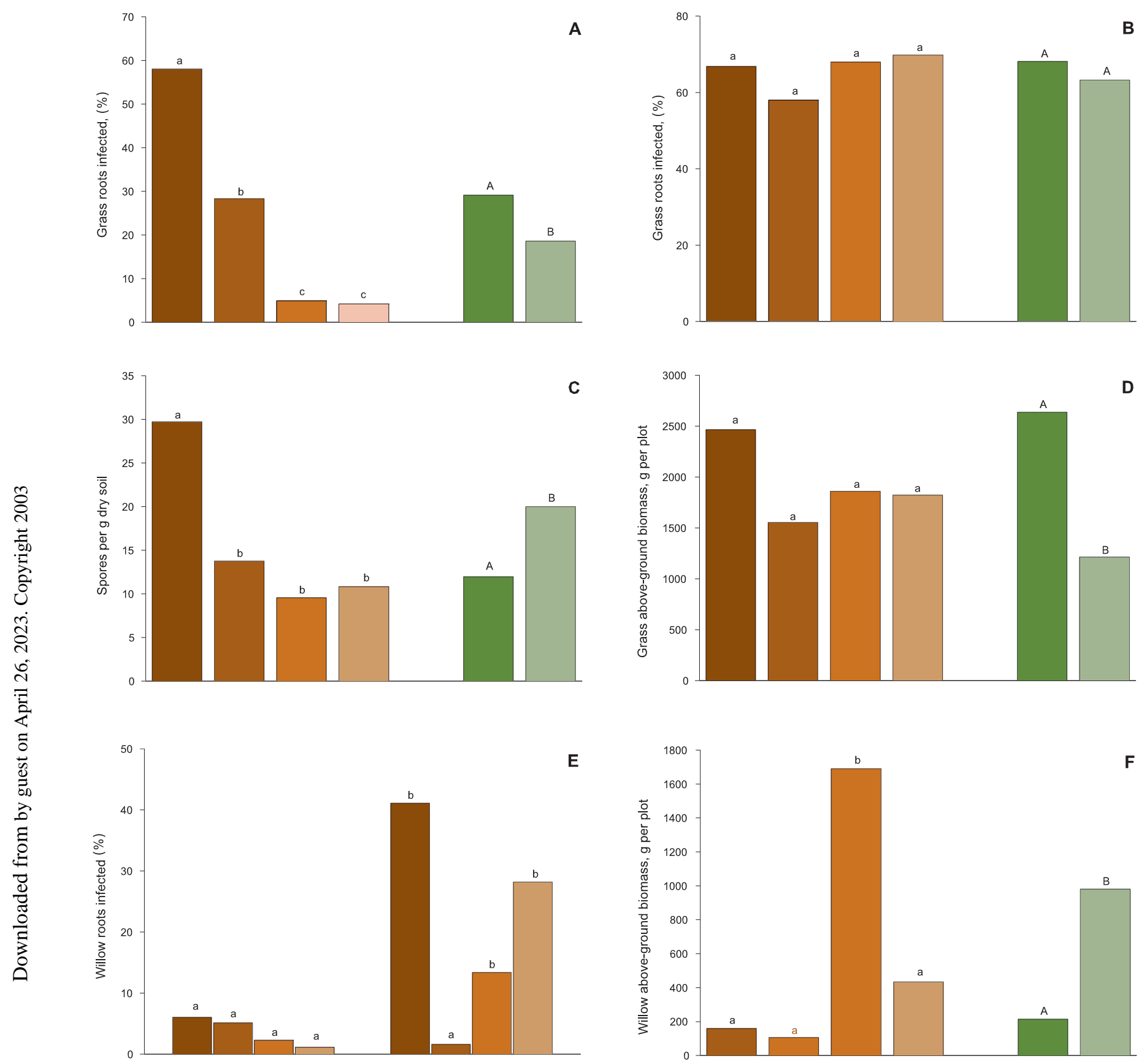

Brome

Hairgrass

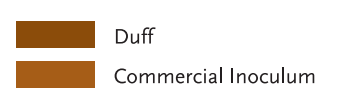

Organic Material

Control

Figure 2. Effects of AMF inoculation or grass species on: AMF colonization of brome and hairgrass roots after (A) 14 wk or

(B) $68 \mathrm{wk}$; (C) mycorrhizal spore counts after $68 \mathrm{wk}$; (D) cumulative (95 wk) above-ground biomass of brome and hairgrass;

(E) AMF colonization of willow roots 57 wk after planting; and (F) above-ground biomass of willow plants 57 wk after planting. 
effective than commercial sources or fungi from other locations (Trappe 1977; Hetrick and others 1986; Perry and others 1987; Sharma and others 1996; Greipsson and El-Mayas 2000). In part, the positive effect of the soil inoculant may be due to higher fungal species diversity. Species diversity has been correlated positively with host plant productivity (Miller and others 1989; Van der Heijden and others 1998; Egerton-Warburton and Allen 2000). Thus, in situations where early colonization is considered important, use of a local soil-based inoculant when available may be preferable to commercial sources.

A likely explanation of the equal colonization rate by inoculated and non-inoculated treatments after 68 wk is that AM fungal strains that were adapted to local soil conditions, which came in after the original inoculation, were better able to colonize roots than fungi collected elsewhere or from a commercial inoculant. A number of reasons for mycorrhizal colonization in untreated plots are possible. Winter rain and wind may have carried soil and other spore-containing debris into the fumigated, non-inoculated plots (Gemma and Koske 1997). Considerable ant activity was visible around and in the plots; ants and other invertebrates, as well as vertebrates, are able to transfer spores from soils containing mycorrhizal fungi to sterile soils (McIlveen and Cole 1976; Allen 1987; Johnson and McGraw 1988). Because soil fumigation does not kill all mycorrhizal spores (McGraw and Hendrix 1984) and often is effective only in the top $15 \mathrm{~cm}$ (6 in) of soil (An and others 1993), it is possible that some spores in the uninoculated plots survived and were propagated to significant numbers as the grasses grew. As has been shown when a grass or forb is seeded on topsoil stockpiles, the spore number is greater in soil grown with a crop than in one left fallow (McGraw and Hendrix 1984; Perry and others 1987).

In our study, both grass species functioned well as quick propagators of mycorrhizal fungi. Considered over a longer time span, use of hairgrass rather than brome may be advantageous as hairgrass supported a higher concentration of spores than brome did after $68 \mathrm{wk}$. Both AMF colonization of willow roots and above-ground willow biomass were greater in plots planted to hairgrass than in those planted to brome. The willow biomass, however, was not correlated either with AMF inoculation or with AMF colonization of roots. It is more likely that differences in willow biomass may be explained by competition between the grasses and the willows, since brome plants accumulated more than twice as much biomass as hairgrass did and therefore probably consumed more water and nutrients. Other researchers have also noted that brome is a faster growing, more productive, and larger grass than hairgrass (Hickman 1993).

In summary, our experiments indicate that inoculation with AMF is not needed in sites where topsoil is present and inoculum sources exist nearby. Native AMF could be applied in 3 ways: 1) from topsoil freshly collected from the site; 2) from stockpiled topsoil, as long as inoculant quality is maintained by a herba- ceous plant cover (Perry and others 1987); and 3) as a "customized" inoculant, that is, local AMF strains that are collected and then propagated commercially. Hairgrass is a good example of a native vegetation cover that can be used to propagate AM fungi on-site, especially if woody plants are to be introduced.

\section{ACKNOWLEDGMENTS}

This study was partially funded by the Hardman Foundation, which supports plant evolutionary and conservation research, and by California Agricultural Experimental Station project CA-AES6258. The authors thank Frank Chan, Ted St John, and Caroline Bledsoe for early guidance in the development of this project, the UC Davis Arboretum staff, and lab assistant Sally Trnka.

\section{REFERENCES}

Allen, MF. 1987. Re? establishment of mycorrhizas on Mount St Helens: migration vectors. Transcriptions British Mycological Society 88:413-417.

An Z, Hendrix JW, Hershman DE, Ferriss RS, Henson GT. 1993. The influence of crop rotation and soil fumigation on mycorrhizal fungal community associated with soybean. Mycorrhiza 3:171-182.

Atkinson D. 1983. The growth, activity and distribution of the fruit tree root system. Plant and Soil 71:23-35.

Boerner RE, DeMars BG, Leicht PN. 1996. Spatial patterns of mycorrhizal infectiveness of soils along a successional chronosequence. Mycorrhiza 6:79-90.

Castellano MA, Molina R. 1989. Mycorrhizae. In: Landis TD, Tinus RW, McDonald SE, Barnett JP, editors. The container tree nursery manual. Volume 5. Washington (DC): USDA Forest Service. Agricultural Handbook No. 674. p 101-167.

Claassen VP, Zasoski RJ. 1993. Enhancement of revegetation on construction fill by fertilizer and topsoil application: effect on mycorrhizal infection. Land Degradation and Rehabilitation 4:45-57.

Egerton-Warburton L, Allen EB. 2000. Shifts in arbuscular mycorrhizal communities along an anthropogenic nitrogen deposition gradient. Ecological Applications 10: 484-496.

Gemma JN, Koske RE. 1997. Arbuscular mycorrhizae in sand dune plants of the North Atlantic coast of the U.S.: field and greenhouse inoculation and presence of mycorrhizae in planting stock. Journal of Environmental Management 50: 251-264.

Gerdemann JW, Nicolson TH. 1963. Spores of mycorrhizal Endogone species extracted from soil by wet sieving and decanting. Transcriptions British Mycological Society 46:235-244.

Giovannetti M, Mosse B. 1980. Evaluation of techniques for measuring vesicular-arbuscular mycorrhizal infection in roots. New Phytologist 84:489-500

Greipsson S, El-Mayas H. 2000. Arbuscular mycorrhizae of Leymus arenarius on coastal sands and reclamation sites in Iceland and response to inoculation. Restoration Ecology 8:144-150. 
Harris JA, Hunter D, Birch P, Short KC. 1989. Vesicular-arbuscular mycorrhizal populations in stored topsoils. Transcriptions British Mycological Society 89:600-603.

Hetrick BAD, Bloom J. 1986. The influence of host plant on production and colonization ability of vesicular-arbuscular mycorrhizal spores. Mycologia 78:32-36.

Hetrick BAD, Kitt DG, Wilson GT. 1986. The influence of phosphorus fertilization, drought, fungal species and nonsterile soil on mycorrhizal growth response in tall grass prairie plants. Canadian Journal of Botany 64:1199-1203.

Hickman JC. 1993. The Jepson manual: higher plants of California. Berkeley (CA): University of California Press. 1400 p.

Hurlbert SH. 1984. Pseudoreplication and the design of ecological field experiments. Ecological Monographs 54:187-211.

Johnson N, McGraw AC. 1988. VA mycorrhizae in taconite tailings. II. Effects of reclamation practices. Agriculture, Ecosystems and Environment 21:143-152.

Kramer CY. 1956. Extension of multiple range tests to group means with unequal numbers of replications. Biometrics 12:307-310.

McGraw AC, Hendrix JW. 1984. Host and soil fumigation effects on spore sporulation densities of species of endogonaceous mycorrhizal fungi. Mycologia 76:122-131.

Mcllveen WD, Cole H. 1976. Spore dispersal of Endogonaceae by worms, ants, wasps and birds. Canadian Journal of Botany 54:1486-1489.

Medve RJ. 1984. The mycorrhizae of pioneer species in disturbed ecosystems in western Pennsylvania. American Journal of Botany 71:787-794.

Menge JA, Timmer LW. 1982. Procedures for inoculation of plants with VA mycorrhizae in the laboratory, greenhouse, and field. In: Schenck NC, editor. Methods and principles of mycorrhizal research. St Paul (MN): American Phytopathological Society Press. p 59-68.

Miller DD, Bodmer M, Schuepp H. 1989. Spread of endomycorrhizal colonization and effects on growth of apple seedlings. New Phytologist 111:51-60.

Miller RM, Carnes BA, Moorman TB. 1985. Factors influencing survival of VA mycorrhiza propagules during topsoil storage. Journal Applied Ecology 22:225-266.

Moorman T, Reeves FB. 1979. The role of endomycorrhizae in revegetation practices in the semi arid west. II. A bioassay to determine the effect of land disturbance on endomycorrhizal populations. American Journal of Botany 66:14-18.

Perry DA, Molina R, Amaranthus MP. 1987. Mycorrhizae, mycorrhizospheres, and reforestation: current knowledge and research needs. Canadian Journal of Restoration 17:929-940.

Pfleger FL, Steward EL, Noyd RK. 1994. Role of AMF fungi in mineland revegetation. In: Pfleger FL, Linderman RG, editors. Mycorrhizae and plant health. St Paul (MN): American Phytopathological Society Press. p 47-81.

Phillips JM, Hayman DS. 1970. Improved procedures for clearing and staining parasitic and VA mycorrhizal fungi for rapid assessment of infection. Transcriptions British Mycological Society 55:158-160.

Sharma MP, Gaur A, Bhatia NP, Adholeya A. 1996. Growth responses and dependence of Acacia nilotica var. cupriciformis on the indigenous arbuscular mycorrhizal consortium of marginal wasteland soil. Mycorrhiza 6:441-446.

St John T. 1997. Arbuscular mycorrhizal inoculation in nursery practice. In: Landis TD, South DB, technical coordinators. National proceedings, forest and conservation nursery associations. Portland (OR): US Depart- ment of Agriculture, Forest Service, Pacific Northwest Research Station General Technical Report PNW-GTR-389. p 152-158.

St John TV, Evans JM. 1990. Mycorrhizal inoculation of container plants Combined Proceedings-International Plant Propagators Society 40:222-231.

Stahl PD, Williams SE, Christensen M. 1988. Efficacy of native VA mycorrhizal fungi after severe soil disturbance. New Phytologist 110: 347-354

Sylvia DM. 1989. Nursery inoculation of sea oats with VA mycorrhizal fungi and outplanting performance on Florida beaches. Journal Coastal Re search 5:747-754.

Sylvia DM, Jarstfer AG. 1994. Production of inoculum and inoculation with arbuscular mycorrhizal fungi. In: Robson AD, Abbott LK, Malajczuk N editors. Management of mycorrhizas in agriculture, horticulture and forestry. Boston (MA): Kluwer Academic Publishers. p 231-238.

Trappe JH. 1977. Selection of fungi for ectomycorrhizal inoculation in nurseries. Annual Review of Phytopathology 15:203-222.

Van der Heijden MGA, Klironomos JN, Ursic M, Moutoglis P, Streitwolf-Engel R, Boller T, Wiemken A, Sanders IR. 1998. Mycorrhizal fungal diversity determines plant biodiversity, ecosystem variability and productivity. Nature 396:69-72.

Walker C, Trappe JM. 1993. Names and epithets in the Glomales and Endogonales, Mycological Research 97:339-344.

\section{AUTHOR INFORMATION}

James R Salyards

Greenhouse Manager

Filoli Center

86 Cañada Road

Woodside, CA 94062

Richard Y Evans

Extension Specialist

ryevans@ucdavis.edu

Alison M Berry

Professor

amberry@ucdavis.edu

Department of Environmental Horticulture

University of California

Davis, CA 95616-8587 